\title{
Effect of Phosphorus and PSB on Growth, Yield and Quality of Blackgram [Vigna mungo (L.) in Inceptisol
}

\author{
R.R. Kachave*, B.S. Indulkar, P.H. Vaidya, A.J. Ingole and N.M. Patil \\ Department of Soil Science and Agriculture Chemistry, College of Agriculture (VNMKV), \\ Latur, Maharashtra, India \\ *Corresponding author
}

Ke y w o r d s
Black gram, Levels
of phosphorus, PSB
(Phosphate
solubilzing
bacteria), Growth,
yield and quality

A B S T R A C T

A field experiment entitled "Effect of phosphorus and PSB on growth, nutrient content, uptake, yield and quality of black gram (Vigna mungo L.) in Inceptisol." was carried out during the Kharif season 2017, at departmental farm of Soil Science and Agricultural Chemistry, College of Agriculture, Latur. The experiment was laid out in RBD with 10 treatment combination along with three replications. The results of field trial on response of black gram to application of different levels of phosphorus and PSB showed beneficial effect on growth, yield and quality of black gram. The growth parameter viz. nodulation, root length and chlorophyll content significantly improved due to application of $100 \% \mathrm{~N}+$ $60 \mathrm{~kg} \mathrm{P}_{2} \mathrm{O}_{5} \mathrm{ha}^{-1}+$ PSB followed by application of $100 \% \mathrm{~N}+50 \mathrm{~kg} \mathrm{P}_{2} \mathrm{O}_{5} \mathrm{ha}^{-1}+$ PSB. Application of $100 \% \mathrm{~N}+60 \mathrm{~kg} \mathrm{P}_{2} \mathrm{O}_{5} \mathrm{ha}^{-1}+\mathrm{PSB}$ was found to be superior for increase in grain and straw yield followed by $100 \% \mathrm{~N}+50 \mathrm{~kg} \mathrm{P}_{2} \mathrm{O}_{5}$ ha $^{-1}+\mathrm{PSB}$ of black gram and also improve the quality of black gram seed in terms of test weight, protein content and protein yield. Among the treatments, application of $60 \mathrm{~kg} \mathrm{P}_{2} \mathrm{O}_{5} \mathrm{ha}^{-1}$ combination along with PSB inoculation showed superiority over all the treatments for improving yield and quality of black gram grown on inceptisol. Thus, it can be concluded that the application of $\mathrm{P}(60 \mathrm{~kg}$ $\mathrm{P}_{2} \mathrm{O}_{5} \mathrm{ha}^{-1}$ ) in combination with PSB recorded statistically superior in growth, yield and quality of black gram as compared to alone application of different levels of $\mathrm{P}$ on low $\mathrm{P}$ content soils of inceptisol.

\section{Introduction}

Pulses occupy a unique position in cropping system as a main, catch, cover, green manure and as intercrop. Pulses play an important role in the Indian diet, constituting one of the most effective sources in India. As per recommendation of World Health Organization (WHO), minimum requirement of pulses is $80 \mathrm{~g} /$ capita/day (Anonymous, 2011-12) but the availability of pulses is very low. Among the pulses, black gram (Vigna mungo L. Hepper) is one of the important pulse crops grown in India which belongs to the family 'Leguminoseae' and genus 'Vigna'. Black gram is a rich protein food. It contains about 24 percent protein, 1.74 per cent fat, 3.5 percent fiber and 67 per cent carbohydrates 
and it is rich source of calcium and iron (Legume Res, 31 (1) 57-59, 2008). Due to high protein and carbohydrate content black gram is used in preparation of Dal makhni in Punjab or the Vada Sambhar, idali, dosa, utthapa in South India. Apart from this, black gram forms excellent forage and it gives a profuse vegetative growth and covers the ground so well that it checks the soil erosion. It also forms a good silage and green manure crop. It has ability to fix about $22.10 \mathrm{~kg}$ of atmospheric nitrogen per hectare through its root nodules. In India 29.28 million hectares land is under pulses cultivation which accounts 22.40 million tones of production. The productivity of pulse crop in India is about $765 \mathrm{~kg} \mathrm{ha}^{-1}$. In India area under black gram crop is 44.93 lakh ha and production is 29.26 lakh tones with the productivity of 651 $\mathrm{kg} \mathrm{ha}^{-1}$. In Maharashtra, 5.75 lakh ha area is under black gram cultivation and production is 3.27 lakh tones with the productivity of $568.70 \mathrm{~kg} \mathrm{ha}^{-1}$. India ranks first in production of black gram (Anonymous, 2016).

Phosphorus stimulates the symbiotic nitrogen fixation because in presence of phosphorus bacterial cell becomes mobile which is pre requisite for migration of bacterial cell to root hair for nodulation (Charel 2006). Phosphorus helps in proper root development which increases root nodules and consequently increases nitrogen fixation. It also plays an important role in the process of photosynthesis, energy conservation and transportation, cell division and meristematic growth in living tissues, grain quality and most of physico-bio-chemical activities.

Phosphate Solubilizing Bacteria (PSB) plays an important role in solubilization of soil $\mathrm{P}$ through secretion of various organic acids (formic, acetic, butyric, propionic, citric, glucomic, succinic, oxalic, malic, maleic and lactic acids) and make it available to plant (Gaur 1991). Many fungi, bacteria and actinomycetes are potential solubilizers of bound phosphates in soil. More over use of PSB also reduce the environmental pollution caused by the heavy use of chemical fertilizers. Application of $\mathrm{P}$ along with PSB, improved phosphorus uptake by plants and yields indicating that the PSB were able to solubilize phosphates and to mobilize phosphorus in crop plants. Therefore, present study was taken to investigate the effect of levels of phosphorus and PSB on yield and quality of black gram.

\section{Materials and Methods}

The present investigation entitled "Effect of Phosphorus and PSB on yield and quality of Black gram [Vigna mungo (L.)] in Inceptisol." was carried out in kharif during 2017-2018. Geographically Latur is situated between $18^{\circ} 05^{\prime}$ to $18^{\circ} 75^{\prime}$ North latitude and $77^{\circ} 36^{\prime} \mathrm{E}$ longitude. It's height from mean sea level is about $633.85 \mathrm{~m}$ and has sub-tropical climate. The experimental soil was clayey in texture, calcareous in nature $(5.9 \%)$, moderately alkaline reaction $(\mathrm{pH} 7.95), \mathrm{EC}\left(0.30 \mathrm{dSm}^{-1}\right)$, low in content of organic carbon $(0.50 \%)$, available zinc $(0.55 \mathrm{ppm})$, available nitrogen $\left(147.60 \mathrm{~kg} \mathrm{ha}^{-1}\right)$, available phosphorous $(9.85$ $\mathrm{kg} \mathrm{ha}{ }^{-1}$ ) and high in available potassium $\left(322.78 \mathrm{~kg} \mathrm{ha}^{-1}\right)$, medium in iron content (4.07 ppm). The experiment was laid out in Randomized Block Design with three replications. The experiment comprised of the ten treatment combinations i.e. control, PSB, $100 \% \mathrm{~N}+30 \mathrm{~kg} \mathrm{ha}^{-1} \mathrm{P}_{2} \mathrm{O}_{5}, 100 \% \mathrm{~N}+40 \mathrm{~kg}$ $\mathrm{ha}^{-1} \mathrm{P}_{2} \mathrm{O}_{5}, 100 \% \mathrm{~N}+50 \mathrm{~kg} \mathrm{ha}^{-1} \mathrm{P}_{2} \mathrm{O}_{5}, 100 \% \mathrm{~N}$ $+60 \mathrm{~kg} \mathrm{ha}^{-1} \mathrm{P}_{2} \mathrm{O}_{5}, 100 \% \mathrm{~N}+30 \mathrm{~kg} \mathrm{ha}^{-1} \mathrm{P}_{2} \mathrm{O}_{5}$ + PSB, $100 \% \mathrm{~N}+40 \mathrm{~kg} \mathrm{ha}^{-1} \mathrm{P}_{2} \mathrm{O}_{5}+\mathrm{PSB}$, $100 \% \mathrm{~N}+50 \mathrm{~kg} \mathrm{ha}^{-1} \mathrm{P}_{2} \mathrm{O}_{5}+\mathrm{PSB}, 100 \% \mathrm{~N}+$ $60 \mathrm{~kg} \mathrm{ha}^{-1} \mathrm{P}_{2} \mathrm{O}_{5}+$ PSB.

The pure seed of Black gram (TAU- 1) was obtained from farm section, College of Agriculture, Latur. Seeds were treated with the liquid PSB (strain- Pseudomonas striata) @ $100 \mathrm{ml} / 10 \mathrm{~kg}$ of seed. Sowing was carried out on $24^{\text {th }}$ June, 2017 by dibbling two seeds at 
each hill at specified spacing $30 \mathrm{~cm} \times 10 \mathrm{~cm}$. Recommended dose of fertilizer $(25: 50: 00 \mathrm{~kg}$ $\mathrm{ha}^{-1}$ ) viz., $100 \%$ nitrogen was applied through urea and phosphorus was applied as per the treatment through SSP before sowing seed. All the recommended cultural and plant protection measures were followed throughout the experimentation. The data on root nodules plant $^{-1}$, root length $(\mathrm{cm})$, chlorophyll content $\left(\mathrm{mg} \mathrm{g}^{-1}\right)$ straw, seed yield $\left(\mathrm{kg} \mathrm{ha}^{-1}\right)$, Test weight $(\mathrm{gm})$, protein content $(\%)$ and protein yield $\left(\mathrm{kg} \mathrm{ha}^{-1}\right)$ was also worked out.

\section{Results and Discussion}

Application of phosphorus and PSB produced significantly higher root length $(\mathrm{cm})$, number of nodules plant ${ }^{-1}$, chlorophyll content $(\mathrm{mg}$ $\mathrm{g}^{-1}$ ) of black gram at 45 DAS showed in Table 1 .

The maximum number of nodules per plant ${ }^{-1}$ root length and chlorophyll content were recorded with the treatment $\mathrm{T}_{6}-100 \% \mathrm{~N}+60$ kg P ha ${ }^{-1} 29.3,24.5$ and (chlorophyll-a 1.10, chlorophyll-b 0.39 , total chlorophyll 2.49) followed by $\mathrm{T}_{5}-100 \% \mathrm{~N}+50 \mathrm{~kg} \mathrm{P} \mathrm{ha}{ }^{-1} 28.6$, 23.9 and (chlorophyll-a 1.09, chlorophyll-b 0.38 , total chlorophyll 2.36) respectively over the control.

Further, the application of different $\mathrm{P}$ levels in combination with PSB inoculation influenced the root length of black gram. The maximum root length was observed in treatment $\mathrm{T}_{10^{-}}$ $100 \% \mathrm{~N}+60 \mathrm{~kg} \mathrm{P} \mathrm{ha}^{-1}+$ PSB 31.4, 26.3 and (chlorophyll-a 1.28, chlorophyll-b 0.48 , total chlorophyll 2.66) followed by $\mathrm{T}_{9}-100 \% \mathrm{~N}+$ $50 \mathrm{~kg} \mathrm{P} \mathrm{ha}{ }^{-1}+$ PSB 30.6, 25.7 and (chlorophyll-a 1.26, chlorophyll-b 0.42 , total chlorophyll 2.55 ) respectively as compared to the other treatments.

The increase in growth attributes due to phosphorus helps in early root development and formation of lateral fibrous, healthy roots and root proliferation. $\mathrm{P}$ increases the metabolic activities and amount of naturally occurring phytohormones. PSB strains released greater amounts of available $\mathrm{P}$ and this enable the plant to absorb more $\mathrm{P}$ resulting in improved growth attributes. Similar results were reported by Niraj et al., (2014), Madholiya (2015) and Vidhyashree $e t$ al., (2017).

Data pertaining to the efficacy of $\mathrm{P}$ and inoculation of PSB on straw yield and grain yield of black gram presented in Table 2. The straw and grain yield of black gram was significantly increased by the application of different levels of $\mathrm{P}$ alone. The maximum increased in straw and grain yield were reported under the treatment $\mathrm{T}_{6}-100 \% \mathrm{~N}+60$ $\mathrm{kg} \mathrm{P} \mathrm{ha}{ }^{-1}$ (2268.84 and $\left.1193.60 \mathrm{~kg} \mathrm{ha}^{-1}\right)$ followed by $\mathrm{T}_{5}-100 \% \mathrm{~N}+50 \mathrm{~kg} \mathrm{P} \mathrm{ha}{ }^{-1}$ (2208.86 and $1160.79 \mathrm{~kg} \mathrm{ha}^{-1}$ ) over absolute control (1910.22 and $\left.997.08 \quad \mathrm{~kg} \mathrm{ha}^{-1}\right)$ respectively.

Whereas, the application of different $\mathrm{P}$ dose in combination with PSB inoculation also influenced the straw and grain yield of black gram. The treatment $\mathrm{T}_{10}-100 \% \mathrm{~N}+60 \mathrm{~kg} \mathrm{P}$ $\mathrm{ha}^{-1}+$ PSB were recorded maximum increased in straw and grain yield (2407.36 and 1258.91 $\mathrm{kg} \mathrm{ha}^{-1}$ ) followed by $\mathrm{T}_{9}-100 \% \mathrm{~N}+50 \mathrm{~kg} \mathrm{P} \mathrm{ha}^{-}$ ${ }^{1}+$ PSB (2358.08 and $1230.45 \mathrm{~kg} \mathrm{ha}^{-1}$ ) respectively as compared to the rest of the treatments.

Alone application of $\mathrm{P}$ levels increased the straw and grain yield in $\mathrm{T}_{6}-100 \% \mathrm{~N}+60 \mathrm{~kg} \mathrm{P}$ $\mathrm{ha}^{-1}$ by $(18.7$ and $19.7 \%)$ while application of $\mathrm{P}$ and PSB also shows significantly increased in straw and grain yield in $\mathrm{T}_{10}-100 \% \mathrm{~N}+60$ $\mathrm{kg} \mathrm{P} \mathrm{ha}{ }^{-1}+\mathrm{PSB}$ by (26.0 and $\left.26.25 \%\right)$ respectively as compared to the control plot. Due to inoculation of PSB treatment shows 5 percent increase in straw yield over absolute control. 
The increased in straw yield might be due to vigorous start to plant and strength straw yield by $\mathrm{P}$ application. The application of $\mathrm{P}$ through SSP also provides $\mathrm{S}$ to the soil and plant which encourages vegetative plant growth, constituent of proteins and enzymes and helps in reduction oxidation system in respiration and increases root growth. Similar results were reported by Appana et al., (2008), Patil et al., (2011) and Gajera et al., (2014). With the application of different $\mathrm{P}$ levels and biofertilizer increased grain yield these could be due to increased availability of photosynthates to the reproductive part during pod filling stage. $\mathrm{P}$ is a constituent of plant cells and involved in transport and conversion of solar energy into simple sugars and energy compounds like ATP and ADP. Microoraganisms through secretion of different organic acids and rhizosphere $\mathrm{pH}$ lowering mechanism dissociates the bound form of $\mathrm{P}$ among various factors that can contribute to crop yield. These results are in conformity with the Balaguravaviah et al., (1989), Gupta et al., (2016) and Prajapati (2014).

Table.1 Effect of P levels and PSB on root length $(\mathrm{cm})$, number of nodules plant ${ }^{-1}$, chlorophyll content $\left(\mathrm{mg} \mathrm{g}^{-1}\right)$ of black gram at 45 DAS

\begin{tabular}{|c|c|c|c|c|c|}
\hline Treatments & $\begin{array}{c}\text { Root } \\
\text { nodules }\end{array}$ & $\begin{array}{l}\text { Root } \\
\text { length }\end{array}$ & $\begin{array}{l}\text { Chlorophyll - } \\
\text { a }\end{array}$ & $\begin{array}{l}\text { Chlorophyll - } \\
\text { b }\end{array}$ & $\begin{array}{c}\text { Total } \\
\text { Chlorophyll }\end{array}$ \\
\hline $\mathrm{T}_{1}-$ Absolute control & 24.53 & 20.7 & 0.85 & 0.29 & 1.75 \\
\hline $\mathrm{T}_{2}-\mathrm{PSB}$ & 25.71 & 22.7 & 0.88 & 0.30 & 1.84 \\
\hline $\mathrm{T}_{3}-100 \% \mathrm{~N}+30 \mathrm{~kg} \mathrm{P}_{2} \mathrm{O}_{5} \mathrm{ha}^{-}$ & 26.79 & 23.1 & 0.93 & 0.35 & 2.05 \\
\hline $\mathrm{T}_{4}-100 \% \mathrm{~N}+40 \mathrm{~kg} \mathrm{P}_{2} \mathrm{O}_{5} \mathrm{ha}^{-}$ & 27.88 & 23.5 & 1.01 & 0.36 & 2.29 \\
\hline $\mathrm{T}_{5}-100 \% \mathrm{~N}+50 \mathrm{~kg} \mathrm{P}_{2} \mathrm{O}_{5} \mathrm{ha}^{-}$ & 28.67 & 23.9 & 1.09 & 0.38 & 2.36 \\
\hline $\mathrm{T}_{6}-100 \% \mathrm{~N}+60 \mathrm{~kg} \mathrm{P}_{2} \mathrm{O}_{5} \mathrm{ha}^{-}$ & 29.33 & 24.5 & 1.10 & 0.39 & 2.49 \\
\hline $\begin{array}{l}\mathrm{T}_{7}-100 \% \mathrm{~N}+30 \mathrm{~kg} \mathrm{P}_{2} \mathrm{O}_{5} \mathrm{ha}^{-} \\
{ }^{1}+\mathrm{PSB}\end{array}$ & 28.41 & 24.6 & 1.21 & 0.41 & 2.28 \\
\hline $\begin{array}{l}\mathrm{T}_{8}-100 \% \mathrm{~N}+40 \mathrm{~kg} \mathrm{P}_{2} \mathrm{O}_{5} \mathrm{ha}^{-} \\
{ }^{-}+\mathrm{PSB}\end{array}$ & 29.49 & 25.1 & 1.24 & 0.40 & 2.41 \\
\hline $\begin{array}{l}\mathrm{T}_{9}-100 \% \mathrm{~N}+50 \mathrm{~kg} \mathrm{P}_{2} \mathrm{O}_{5} \mathrm{ha}^{-} \\
{ }^{-} \mathrm{PSB}\end{array}$ & 30.69 & 25.7 & 1.26 & 0.42 & 2.55 \\
\hline $\begin{array}{l}\mathrm{T}_{10}-100 \% \mathrm{~N}+60 \mathrm{~kg} \mathrm{P}_{2} \mathrm{O}_{5} \\
\mathrm{ha}^{-1}+\mathrm{PSB}\end{array}$ & 31.48 & 26.3 & 1.28 & 0.48 & 2.66 \\
\hline $\mathrm{SE} \pm$ & 0.46 & 0.35 & 0.028 & 0.029 & 0.038 \\
\hline CD@ $5 \%$ & 1.38 & 1.05 & 0.079 & 0.082 & 0.11 \\
\hline
\end{tabular}


Table.2 Effect of P levels and PSB inoculation on straw and grain yield $\left(\mathrm{kg} \mathrm{ha}^{-1}\right)$ of black gram

\begin{tabular}{|l|c|c|}
\hline \multicolumn{1}{|c|}{ Treatments } & Straw yield & Grain yield \\
\hline $\mathrm{T}_{1}-$ Absolute control & 1910.22 & 997.083 \\
\hline $\mathrm{T}_{2}-\mathrm{PSB}$ & 2007.89 & 1019.33 \\
\hline $\mathrm{T}_{3}-100 \% \mathrm{~N}+30 \mathrm{~kg} \mathrm{P}_{2} \mathrm{O}_{5} \mathrm{ha}^{-1}$ & 2122.54 & 1084.17 \\
\hline $\mathrm{T}_{4}-100 \% \mathrm{~N}+40 \mathrm{~kg} \mathrm{P}_{2} \mathrm{O}_{5} \mathrm{ha}^{-1}$ & 2183.92 & 1132.69 \\
\hline $\mathrm{T}_{5}-100 \% \mathrm{~N}+50 \mathrm{~kg} \mathrm{P}_{2} \mathrm{O}_{5} \mathrm{ha}^{-1}$ & 2208.86 & 1160.79 \\
\hline $\mathrm{T}_{6}-100 \% \mathrm{~N}+60 \mathrm{~kg} \mathrm{P}_{2} \mathrm{O}_{5} \mathrm{ha}^{-1}$ & 2268.84 & 1193.60 \\
\hline $\mathrm{T}_{7}-100 \% \mathrm{~N}+30 \mathrm{~kg} \mathrm{P}_{2} \mathrm{O}_{5} \mathrm{ha}^{-1}+\mathrm{PSB}$ & 2247.02 & 1143.27 \\
\hline $\mathrm{T}_{8}-100 \% \mathrm{~N}+40 \mathrm{~kg} \mathrm{P}_{2} \mathrm{O}_{5} \mathrm{ha}^{-1}+\mathrm{PSB}$ & 2299.09 & 1188.91 \\
\hline $\mathrm{T}_{9}-100 \% \mathrm{~N}+50 \mathrm{~kg} \mathrm{P}_{2} \mathrm{O}_{5} \mathrm{ha}^{-1}+\mathrm{PSB}$ & 2358.08 & 1230.45 \\
\hline $\mathrm{T}_{10}-100 \% \mathrm{~N}+60 \mathrm{~kg} \mathrm{P}_{2} \mathrm{O}_{5} \mathrm{ha}^{-1}+\mathrm{PSB}$ & 2407.36 & 1258.91 \\
\hline $\mathrm{SE} \pm$ & 17.66 & 18.73 \\
\hline $\mathrm{CD} @ 5 \%$ & 52.42 & 55.67 \\
\hline
\end{tabular}

Table.3 Effect of P levels and PSB inoculation on test weight (gm), protein content (\%) in seed and protein yield $\left(\mathrm{kg} \mathrm{ha}^{-1}\right)$ of black gram

\begin{tabular}{|l|c|c|c|}
\hline \multicolumn{1}{|c|}{ Treatments } & Test weight & $\begin{array}{c}\text { Protein } \\
\text { content }\end{array}$ & Protein yield \\
\hline $\mathrm{T}_{1}$ - Absolute control & 40.62 & 20.15 & 200.81 \\
\hline $\mathrm{T}_{2}-\mathrm{PSB}$ & 41.32 & 20.36 & 207.60 \\
\hline $\mathrm{T}_{3}-100 \% \mathrm{~N}+30 \mathrm{~kg} \mathrm{P}_{2} \mathrm{O}_{5} \mathrm{ha}^{-1}$ & 42.57 & 20.83 & 228.42 \\
\hline $\mathrm{T}_{4}-100 \% \mathrm{~N}+40 \mathrm{~kg} \mathrm{P}_{2} \mathrm{O}_{5} \mathrm{ha}^{-1}$ & 42.79 & 21.79 & 248.39 \\
\hline $\mathrm{T}_{5}-100 \% \mathrm{~N}+50 \mathrm{~kg} \mathrm{P}_{2} \mathrm{O}_{5} \mathrm{ha}^{-1}$ & 43.97 & 22.10 & 256.59 \\
\hline $\mathrm{T}_{6}-100 \% \mathrm{~N}+60 \mathrm{~kg} \mathrm{P}_{2} \mathrm{O}_{5} \mathrm{ha}^{-1}$ & 44.48 & 22.70 & 266.66 \\
\hline $\mathrm{T}_{7}-100 \% \mathrm{~N}+30 \mathrm{~kg} \mathrm{P}_{2} \mathrm{O}_{5} \mathrm{ha}^{-1}+$ & 43.50 & 22.37 & 255.76 \\
\hline $\mathrm{PSB}$ & & & \\
\hline $\mathrm{T}_{8}-100 \% \mathrm{~N}+40 \mathrm{~kg} \mathrm{P}_{2} \mathrm{O}_{5} \mathrm{ha}^{-1}+$ & 43.94 & 22.81 & 269.77 \\
\hline $\mathrm{PSB}$ & & & \\
\hline $\mathrm{T}_{9}-100 \% \mathrm{~N}+50 \mathrm{~kg} \mathrm{P}_{2} \mathrm{O}_{5} \mathrm{ha}^{-1}+$ & 44.86 & 23.22 & 285.91 \\
\hline PSB & & & \\
\hline $\mathrm{T}_{10}-100 \% \mathrm{~N}+60 \mathrm{~kg} \mathrm{P}_{2} \mathrm{O}_{5} \mathrm{ha}^{-1}+$ & 45.65 & 23.77 & 294.46 \\
\hline $\mathrm{PSB}$ & & & \\
\hline $\mathrm{SE} \pm$ & 2.83 & 0.23 & 6.28 \\
\hline $\mathrm{CD} @ 5 \%$ & 0.70 & 18.67 \\
\hline
\end{tabular}


Data regarding the Effect of $\mathrm{P}$ levels and PSB culture on test weight, protein content and protein yield of black gram reported in Table 3. Different levels of $\mathrm{P}$ alone were significantly increased the test weight. The treatment $\mathrm{T}_{6}-100 \% \mathrm{~N}+60 \mathrm{~kg} \mathrm{P} \mathrm{ha}^{-1}(44.48$ gm) followed by $\mathrm{T}_{5}-100 \% \mathrm{~N}+50 \mathrm{~kg} \mathrm{P} \mathrm{ha}^{-1}$ (43.97 gm) over absolute control. Whereas, the successive application of different $\mathrm{P}$ levels along with PSB also enhance the test weight of black gram. Maximum test weight were observed in treatment $\mathrm{T}_{10}-100 \% \mathrm{~N}+60 \mathrm{~kg} \mathrm{P} \mathrm{ha}{ }^{-1}+\mathrm{PSB}$ $(45.65 \mathrm{gm})$ followed by $\mathrm{T}_{9}-100 \% \mathrm{~N}+50 \mathrm{~kg} \mathrm{P}$ $\mathrm{ha}^{-1}+$ PSB (44.86 gm) as compared to control, single and combined application of $\mathrm{P}$ and PSB.

$\mathrm{P}$ application increased the test weight by stimulating flowering and aids in seed formation. Increase in test weight due to more number of heavy weighed and bold seeds with application of P and PSB. Similar results were reported by the Ullah et al., (2010) and Verma et al., (2017).

Protein content in seed and protein yield were significantly affected by the application of various $\mathrm{P}$ dose. The higher protein content and protein yield of black gram were observed under the treatment $\mathrm{T}_{6}-100 \% \mathrm{~N}+60$ $\mathrm{kg} \mathrm{P} \mathrm{ha}{ }^{-1}(22.70 \%$ and $266.66 \mathrm{~kg}$ ha-1) followed by $\mathrm{T}_{5}-100 \% \mathrm{~N}+50 \mathrm{~kg} \mathrm{P} \mathrm{ha}{ }^{-1}(22.10$ $\%$ and $256.59 \mathrm{~kg}$ ha-1) respectively over absolute control.

The data further revealed that the combined application of $\mathrm{P}$ at different levels + PSB inoculation increased the protein content and protein yield of black gra. The higher protein content and protein yield was recorded under the treatment $\mathrm{T}_{10}-100 \% \mathrm{~N}+60 \mathrm{~kg} \mathrm{P} \mathrm{ha}^{-1}+$ PSB (23.77 \% and $294.46 \mathrm{~kg} \mathrm{ha}^{-1}$ ) followed by $\mathrm{T}_{9}-100 \% \mathrm{~N}+50 \mathrm{~kg} \mathrm{P} \mathrm{ha}{ }^{-1}+\mathrm{PSB}(23.22 \%$ and $285.91 \mathrm{~kg} \mathrm{ha}^{-1}$ ) respectively over the rest of treatments. The increase in protein content of seed due to higher supply of $\mathrm{N}$ through solubilization function of PSB. P helps in root enlargement, better microbial activities resulted in more availability and uptake of $\mathrm{N}$ thereby, increased protein content increase in protein content ultimately resulted in increased protein yield. Similar results were reported by Gadhavi et al., (2005), Madane et al., (2014) and Dongare et al., (2016)

\section{References}

Anonymous (2016) Annual report on pulses. Agric. Statistics at a glance, www.dacnet.nic.in/ean.

Appanna, V., Alagawadii, A. R., Hamezehzarghani, H. and Krishnaraj, P. U. (2008). Efficiency of phosphate solubilizing bacteria on the yield and phosphorus uptake of green gram (Vigna Radiata (L.) wilczek). The Americas J. of plant Sci. and Biotec.

Balaguravaiah, D., Narasimha Rao, Y., Adinarayana, V., Narasimha, R. and Subba Rao, I. V. (1989) Phosphorus requirement of green gram. J. Indian Soc. Soil Sci. Vol. 37: 738-743.

Charel, J. D. (2006). Response of green gram [Vigna radiate (L.) wilczek] to phosphorus and sulphur with and without PSB inoculation. M. Sc. Thesis, Aaanand Agricultural University, Aanand.

Dongare, D. M., Pawar, G. R., Murumkar, S. B. and Chavan, D. A. (2016). To study the effect of different fertilizers and bio-fertilizer levels on growth and yield of summer green gram. Int. J. of Agril. Sci., Vol. 12 (2), 151-157.

Gadhavi, J. B. (2005). Influence of irrigation schedules (IW: CPE ratio) and biofertilizers on growth and yield of summer black gram [Phaeolus mungo (L.) Hepper] under middle Gujrat condition. M. Sc. (Ag.) Thesis, Agronomy, B. A. College of 
Agricultural, Aanand Agricultural University Aanand.

Gajera, R. J., Khafi, H. R., Raj, A.D., Yadav, V. and Lad, A. N. (2014). Effect of phosphorus and bio-fertilizers on growth yield and economics of summer green gram [Vigna radiate (L.) Wilczek]. Agric. Update, 9 (1): 98-102.

Gaur A. C. (1991). Phosphate solubilizing microorganism and bio-fertilizers. Omega Scientific Publishers, New Delhi. 176.

Gupta, A. and Sharma, V. K. (2006). Studies on the effect of biofertilizersand phosphorus levels on yield and economics of urdbean (Vigna mungo L. Hepper). Legume Res., 29 (4): 278281.

Madane, A. J., Chavan, M.G., Rajemahadik, V. A. and Singh, J. K. (2014). Response of summer black gram (Vigna mungo) varieties to phosphorus levels under lateritic soils of konkan. Internat. J. Sci. Engg. And Tech. Vol. No. 3, pp: 259-262.

Madholiya, N. S. (2015). Integrated crop management practices for maximization of yield of black gram [Vigna mungo (L.) hepper]. M. Sc. (Ag.) Thesis, Rajmata Vijayaraje Scindia Krishi Vishwa Vidyalaya, Gwaliar (MP).

Niraj, V. P. S. and Prakash, Ved (2014). Effect of phosphorus and sulphur on growth, yield and quality of black gram (Phaseolus mungo L.). Asian J.
Soil sci., 9 (1): 117-120.

Patil, S.C., Jagtap, D. N. and Bhale, V.M. (2011). Effect of phosphorus and sulphur on growth and yield of moong bean. Internat. J. agric. Sci., 7 (2): 348-351.

Prajapati, C. K. (2014). Influence of irrigation scheduling based on critical growth stages and phosphorus with PSB and without PSB inoculation on growth, yield attributes and yield of summer black gram (Phaseolus mungo L. Hepper) under middle Gujrat condition. M. Sc. (Ag.), Thesis, B. A. College of Agriculture, Aanand Agril. University, Aanand.

Ullah, A., Ali, A., Waseem, M., Nadeem, M. A., Tahir, M., Iqbal, A. and Rehman, H. (2010). Response of two mung bean cultivars with different phosphorus levels under Faisalabad condition. Int. J. of Applies Agric. Res., 5 (5) pp. 621-628.

Verma, G., Kumawat, N. and Morya, J. (2014). Nutrient management in mung bean [Vigna radiate $(\mathrm{L}$.$) Wilczek] for$ higher production and productivity under semi-arid tract of central India. Int. J. Curr. Microbial. App. Sci 6 (7): 488-493.

Vidhyashree, V., Naga, S. R., Yadav, B. L., Koli, D. K. and Rao, I. J. (2017). Effect of phosphorus and biofertilizers on growth and yield of mungbean [ Vigna radiate (L.) Wilczek]. Int. J. Curr. Microbial. App. Sci., 6(7): 39923997.

\section{How to cite this article:}

Kachave, R.R., B.S. Indulkar, P.H. Vaidya, A.J. Ingole and Patil, N.M. 2018. Effect of Phosphorus and PSB on Growth, Yield and Quality of Blackgram [Vigna mungo (L.) in Inceptisol. Int.J.Curr.Microbiol.App.Sci. 7(07): 3359-3365. doi: https://doi.org/10.20546/ijcmas.2018.707.391 